\title{
The Dynamics of Tianguá's Ceasa Modifying the Economic Relation among the Municipalities from Ibiapaba Sierra (CE)
}

\author{
Marilia de Araujo Fontenele \\ Geography Master Program student at MAG \\ Vale do Acaraú State University/UVA, Ceará, Brazil \\ Aldiva Sales Diniz \\ PhD in Geography and Professor at MAG/UVA \\ Antonia Vanessa Silva Freire Moraes Ximenes \\ $\mathrm{PhD}$ in Geography and Teacher in the Basic Education of the State of Ceará
}

\begin{abstract}
The following article aims to present Ibiapaba Plateau as a reference one by acting and being responsible for boosting the economic flux that involves many municipalities belonging to Ibiapaba, which weekly transport their fruit and vegetable production to Tianguá 's Ceasa. Calling upon the dialectical method, observations and data records, it was strived to comprehend the importance of Ibiapaba Sierra and the relations involving small producers and workers who weekly dedicate themselves to load and unload trucks with vegetables that arrive at Ceasa and after that depart to other cities and nearby states.
\end{abstract}

Keywords: Small producers; Ceasa; Ibiapaba Plateau.

\section{Introduction}

Ibiapaba Plateau, also known as Big Sierra or Ibiapaba Sierra, is in the Ceará's Northwest mesoregion, on the border with Piauí. According to some data provided by the Brazilian Institute of Geography and Statistics (IBGE), there are more than 335 thousand inhabitants living all around the eight municipalities from Ibiapaba, namely São Benedito, Guaraciaba do Norte, Carnaubal, Croatá, Ubajara, Ibiapina, Viçosa do Ceará and Tianguá.

Such municipalities altogether make Ibiapaba a local and regional reference in the production of vegetables and fruits. The closeness between Ibiapaba and Sobral is had as an important factor since it promotes a strong bond among Ibiapaba's municipalities and Sobral through services which are offered in the sectors of education, health and trade, characterizing a great and intense flux of people who search for such services.

Ibiapaba or Big Sierra, as it is popularly known, has always been attached to speeches about wealth and prosperity, a place in where many historic accounts from a long time ago are related to the abundance and exuberant beauty present in that region. Such speeches are proved to be true by considering Antonio Bezerra's travel notes (1965), who says: I have not seen so much excitement yet, so much service, and it comes to confirm a judgement that I did myself concerning the importance, the prosperity that everyone must come and enjoy the Big Sierra as soon as its sources of wealth are recognized. (BEZZERA, 1965, p. 174).

As stated by Bezerra (1965), the sources of wealth and the rich resources available in Ibiapaba, which had been hidden for a long time from the capital interest, did not go unnoticed to politicians and other greedy people from the current hegemonic exploitation, which penetrates territories and destroy their historic heritage.

Based on the role and importance that Ibiapaba plays in the state of Ceará, it was sought, in this essay, to approach through visits made to Ceasa, photos and observation records - the relation of the commerce which moves those municipalities' economy and employs hundreds of people in weekly activities such as buying and selling fruits and vegetables.

\section{The New Investments Which Move Ibiapaba's Economic Relation}

Not different from what happened in another Brazilian regions, which at first did not mean an attractive to capitalist investments, they present themselves as sources of wealth worthy of investments. The dimension that agribusiness has acquired in Ibiapaba Sierra has been a motive of concern due to the power of agro-industries and the dynamization they cause in spaces. 
Several examples may be pointed out in this region, among them, the facilities mechanisms of a multinational corporation called Nutrilite in Ubajara, where is clearly seen one of the agrobusiness models, that is, foreign companies buying acerola from small and medium producers and creating a production circle through acerola pulp production and the final product traded in United States of America and China.

In those two countries, the final product of the process performed in Brazil is used as vitamin supplement amongst others uses. The company in charge of transporting all products derived from fruits grown in the countryside of Ceará does not sell its products in the city and not even in other cities in the same state. The proof of this is that it is not found in Ibiapaba not even one of its stores with products to be consumed by the producers. All profit and benefits from trading stay abroad.

An additional fact is the recent and remarkable presence of wind farms, which are one more example of political interests of a capitalist State to penetrate territories and modify the relations to benefit production capitalist relations, meeting the interests of corporate groups.

Although it is widely spoken about the various benefits of the so-called clean energy, the local population still does not understand who in fact will be benefited and when are such benefits coming. What have been noticed so far is a huge turmoil in eolic facilities that has changed the surrounding population's life which now lives with the facilities' noise and other disturbances, besides others changings caused to the local ecological community.

Therefore, Ibiapaba, where agrobusiness was rarely heard about until some time ago, has been shaped due to proposals arisen from investments and production capitalist business people and their interventions in space and farmers' daily life.

To small producers who are engaged in family farming, the sense of land and the view they have while production are different from the ones had by a capitalist producer, who uses land aiming only labor exploitation and profit through this work and lack of resources.

Regarding this, Martins (1991) emphasizes that in the family system, work is what legitimize the right to property; in contrast, in the property capitalist system, labor exploitation is the reason of its existence.

The capitalist property is a different property system. It is based on the principle of exploitation that the capital has over a worker who does not possess neither tools nor instruments to work, what is now possessed by the capitalist property. In this case, it is a variation of the private property, being different because it is the property that has the task of assuring to the capital the right of labor exploitation. It is necessarily an exploitation tool. Thus, it must not be mistaken capitalist property for family property and vice-versa.

The family property is not a property of whom exploits others' work; it is a direct property of work tools on behalf of those who work. It is not a capitalist property, but a worker's one instead. Its social results are totally different, because in this case the production and reproduction of life conditions is not established by the necessity of profit [...] When land is appropriated by the capital, it turns into a business land, others' exploitation land; when land is appropriated by a worker, it turns into a work land (MARTINS 1991 p. 54 - 55).

Accordingly, Diniz (2009) stresses, in the capitalism logic, that land stands as a business object in which profit is earned through labor exploitation and, consequently, through the added value extraction and being also kept as a store of value according to an established order, one which is focused on both economy and land as business, what enters in a direct confrontation along with the rural order, in which land is had as a life reproduction axis.

Ibiapaba's land has always supported the production of fruits and vegetables produced by small farmers It currently shelters the production of flowers and, even though it has always existed small flower crops, activities from this sector were not intended to a large-scale trading, but only for a local trading instead. The municipality of São Benedito, where soil and climatic conditions has cooperated to the development of such activity, is now a national and international reference in the floristic business, ranking Ceará in the second position among the greatest Brazilian flower producers.

Since there were not any experts in the area, and worse, the municipality was not provided with such services, the installation service of farms was initially carried out by foreign technicians and all the technology necessary to set up and keep greenhouses so the first production could be ensured and the risk of loss be minimum.

The growing process of the floristic sector in Ibiapaba was triggered by the companies Cearosa, the first company in the area which was settled in São Benedito in 2000, Reijers, in 2001, Flora Fogaça and Grupo Swart, as stated by Costa (2017). 
In conformity with Terra (2013), the floristic sector has a high cost of products when compared to others such as fruits and vegetables. This fact does not take into account small producers who do not have neither enough money nor power to compete against companies which are directly benefited by State public policies created exclusively to meet the necessities of such sector.

In the context, it is clearly noticed that the government has stopped investing in public policies that benefit small producers as it is the case in Ibiapaba, leading the country to the path of exploitation and destruction policies concerning natural wealth and resources, consequently threatening the lives of those who live in the countryside and their peaceful coexistence with nature.

\section{Ceasa And Its Workers' Routine in Tianguá - Ce}

The presence of a peasant agriculture in Ibiapaba is quite remarkable due to the development of the fruits and vegetables sectors and the basic products (Table 01), which are responsible for supplying many surrounding municipalities and even other states.

Considering the data from Tianguá's Ceasa, the volume of fruits and vegetables produced in 2018 totalized 33.087,4 tons. This number includes fruits, vegetables and cereals traded in the local. The participation of Ibiapaba's municipalities is the greatest firstly in Tianguá and secondly in Guaraciaba as presented in Table 01.

Table 01: Table of volume and participationofIbiapaba's municipalities.

\begin{tabular}{|c|c|c|}
\hline MUNICIPALITY & VOLUME & $\begin{array}{c}\text { PARTICIPATIONX } \\
(\mathrm{R} \$)\end{array}$ \\
\hline Tianguá & 755,5 & $1.343 .604,30$ \\
\hline Guaraciaba do norte & 688,9 & $877.746,83$ \\
\hline São Benedito & 639,3 & $881.570,30$ \\
\hline Ubajara & 500,4 & $738.615,64$ \\
\hline Viçosa do Ceará & 238,9 & $338.850,42$ \\
\hline Ibiapina & 199,0 & $280.249,23$ \\
\hline Croatá & 95,3 & $137.790,43$ \\
\hline Carnaubal & 22,0 & $26.848,07$ \\
\hline
\end{tabular}

Source: Tianguá's Ceasa. Economic Analysis 2018. Organized by Fontenele (2018)

As presented in the table above, the productive collaboration of Tiangua and Guaraciaba is notorious due to the great production volume that moves Ibiapaba, thus generating an income responsible for moving the commerce in the region.

The producers who supply Ceasa live in farms and villages and are in charge of the weekly fairs which take place on Tuesdays and Fridays in Tianguá (Image 01 and 02). In those fairs, shoppers drive to Sierra, then load their trucks and finally travel to the several deliverances destines inside and outside the state.

Image01: Boxes Area.



Source: Fontenele (2018) 


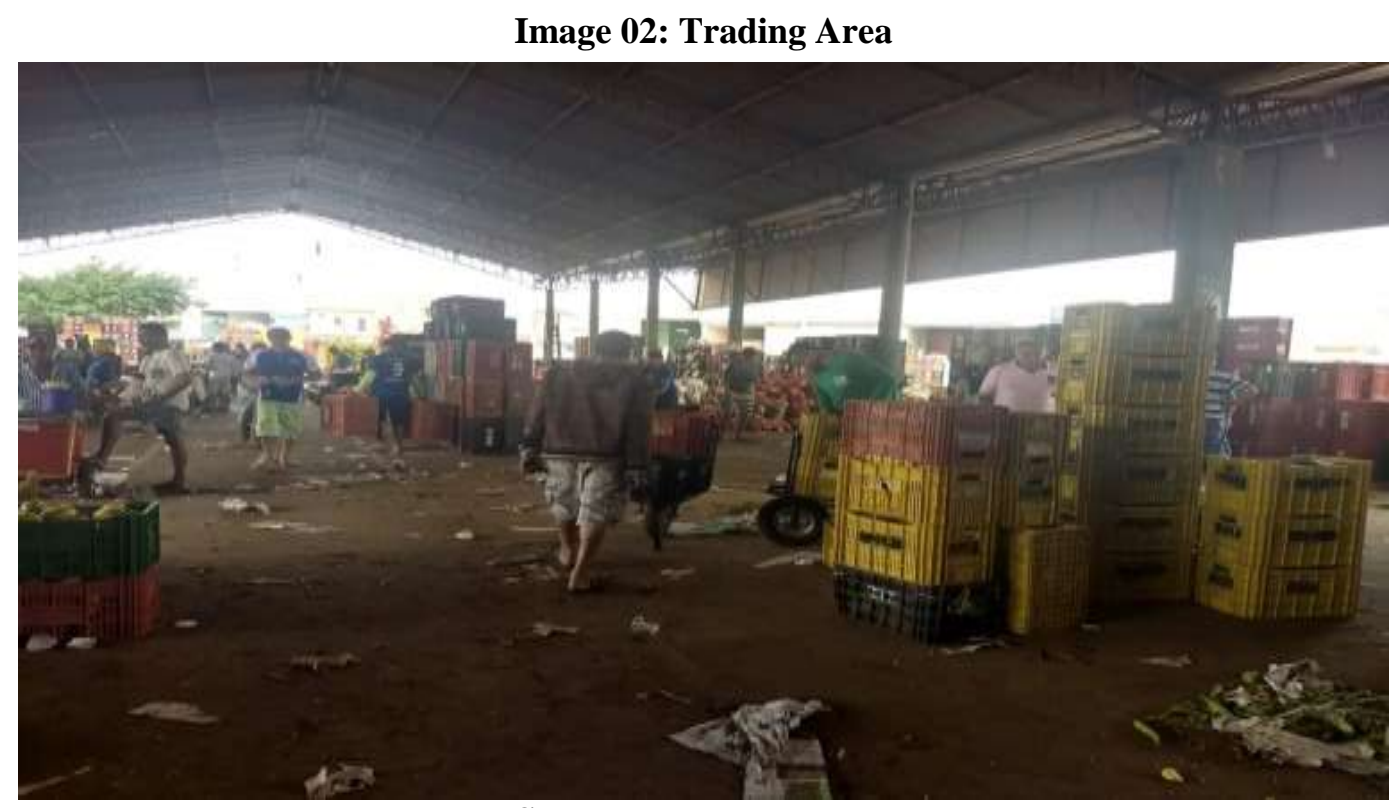

Source: Fontenele (2018)

Characterized by generating income, Ceasa involves many kinds of producers - from businesspeople to farmers. In fair days, the area gets mostly crowded by people in charge of setting up and organizing loads which arrive at Ceasa to be sold and then they are taken to warehouses, where they are organized to be sent to their destines.

All the businesspeople in this sector have their own group of loaders, most of them come from the countryside and carry heavy vegetables sacks and boxes for a living, as shown in the image below.

Image 03: Sacks and boxes at Tianguá's Ceasa.

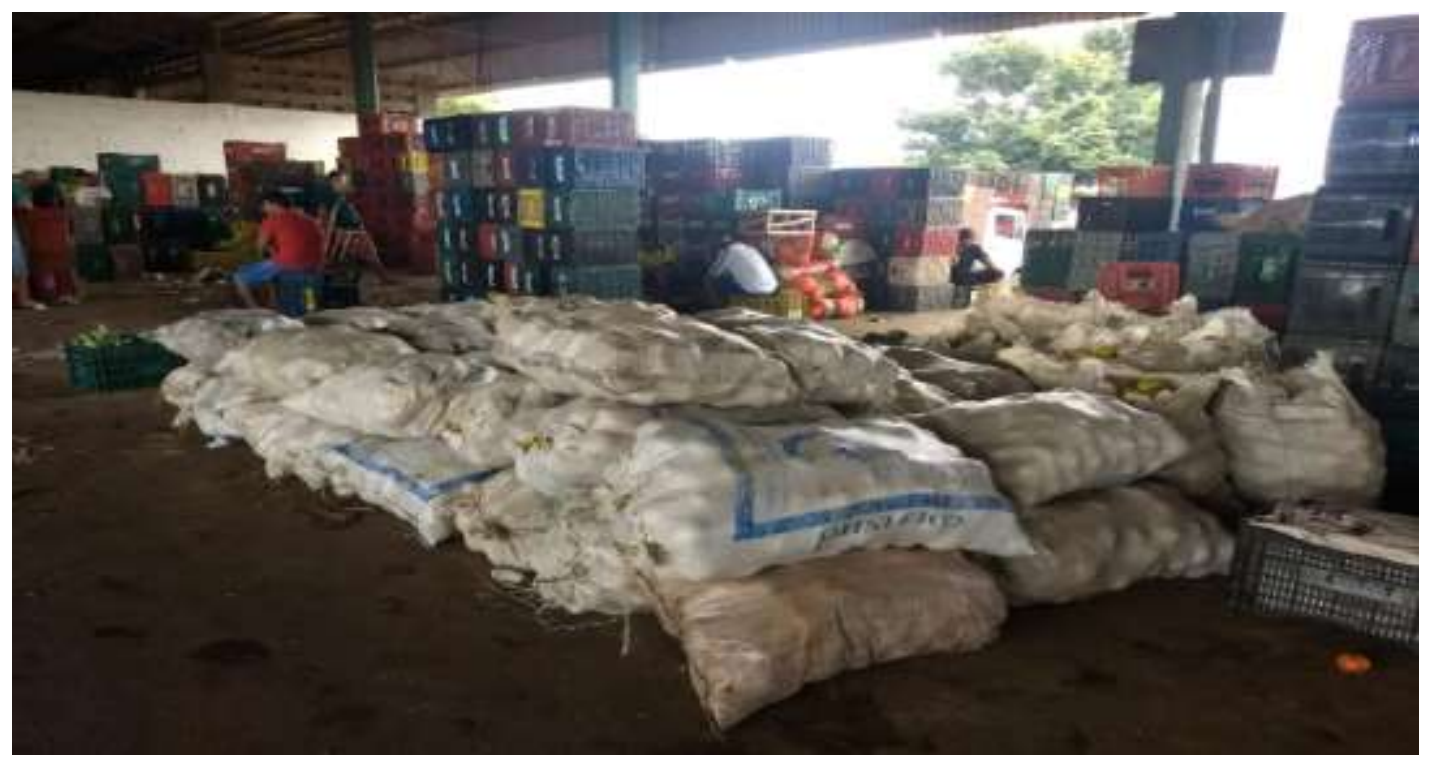

Source: Fontenele (2018)

The notorious presence of Ceasa in Tianguá makes the neighborhood where it is placed in receive the name of Ceasa's Neighborhood. Such presence modifies the spatial dynamic and the daily life in the city and close municipalities by altering the flow of people among them.

It is also observed in Image 04 that there are not houses on the streets surrounding Ceasa, but only warehouses of local businesspeople who rent them as spaces to organize the loads weekly bought at Ceasa and then taken to other places. 


\section{Image 4: Vegetable warehouses on the streets next to Ceasa,}

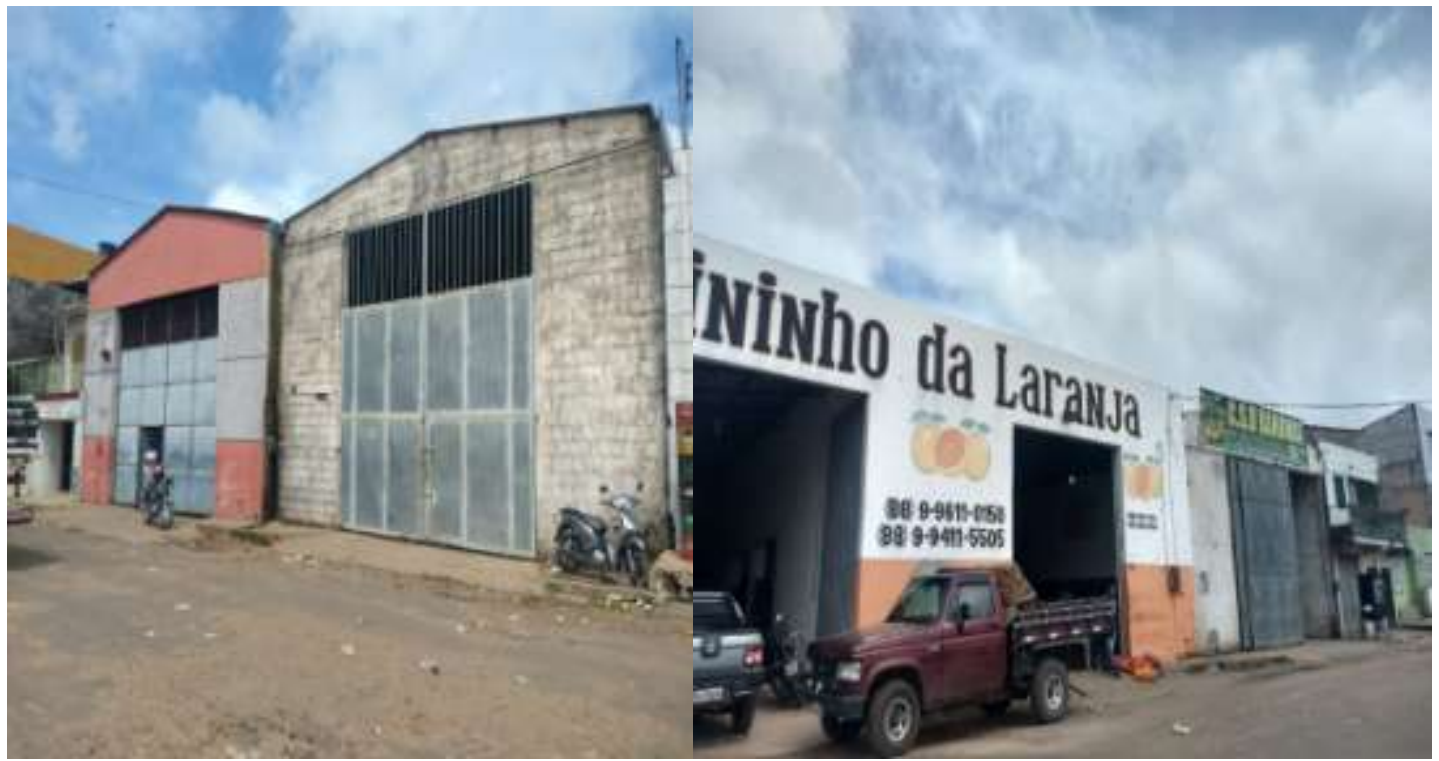

Source: Fontenele (2018)

The reality of those who produce fruits and vegetables in Ibiapaba is constituted mostly by producers who do not manage to have a considerable improvement of their products once they rely on governmental projects that do not benefit small properties.

According to the local EMATECE, it is necessary for a producer to have $30 \%$ of the price of a car to finance one so he may work and transport the products he grows to Ceasa's fair. As they do not manage to get this money, they stay out of the market and are forced to sell the products they grow so they do not get rotten.

In this regard, Fernandes (2013) reveals that resources and loans are made available for agribusiness, whereas only a small portion is intended for small farmers, fact which places them out of the profit and wealth process.

The agrarian Brazil is quite unfair because $74 \%$ of the farmers receive only $15 \%$ of the agricultural credit, have only $24 \%$ of the arable land and produce $38 \%$ of the gross. It is a little land for too many people receiving small loans and divide the rest of the produced wealth, that is, the part the capital allowed to stay with the peasantry. On the other hand, agribusiness keeps $85 \%$ of the agricultural credit, controls $76 \%$ of the arable land, produces $65 \%$ of the gross and employs approximately $26 \%$ of the people. (FERNANDES, 2013, p. 96).

Farmers who do not dispose of assets to market their products are forced to sell them to middlemen who buy the merchandise and take them to Ceasa or sell them to fixed clients who visit their establishments and buy the products.

The figure of the middleman is depicted by Ximenes (2015) when she says that this group is represented by businesspeople who often visit farmers' properties, buy their products and take them to the consumer market where they are sold in retail and wholesale. The value of those products is established by middlemen who say they base themselves on the market value, depending on the law of supply and demand.

The products purchasing policies work like that: if a middleman goes to a farmer's property to buy his products, he gets them cheaper than he would if the farmer took his fruits, vegetables or cereals to Ceasa, where it is sold according to the market price. In this reality, farmers lose part of profit he would get considering they have a hard work with land.

\section{Final Considerations}

As presented, it is possible to state that Ibiapaba Plateau, or popularly Ibiapaba Sierra, plays a relevant role in the dynamic of economy in the state of Ceará and it has drawn the attention of great businesspeople who search for territory so they can invest agribusiness models similar to the ones already existent in Ibiapaba.

Ceasa's presence has been responsible for linking Ibiapaba to all the other cities in Ceará and even the ones from neighboring states and, consequently, has created formal and informal jobs that reveal workers' difficulties who weekly earn money from Ceasa's fairs, jeopardizing their own lives and making little money from the works they carry out.

To Ceasa's workers, besides being a heavy work on trucks, like loading and unloading boxes, they also travel on highways over the loads, jeopardizing their lives in reason of the few opportunities of jobs they have. 
Therefore, if public policies were improved and small farmers could be benefited from them, the countryside would be a place with more opportunities and equality of services. Not as in the case of what was considered in this research, that a big portion of those who perform all service receive just a little or almost nothing of payment.

\section{Bibliographic References}

BEZERRA, Antônio. Travel Notes. Fortaleza. Ceará'sUniversity Press, 1965.

CEASA. Tianguá's Ceasa EconomicAnalysis. 2018

COSTA, Kassia Kiss Silva; CAVALCANTE, Leandro Vieira. THE FLORISTIC AGRIBUSINESSIN IBIAPABA/CE: the Stateroleand theCapital. In: VIII International Symposiumof Agrarian Geographyand IX National Symposiumof Agrarian Geography. Curitiba, November 1 to 5,2017.

DINIZ, Aldiva Sales. WALKING THROUGH: The peasant resistenceinCearáinthepursuit of itsfreedom. $\mathrm{PhD}$ Thesis (PhDin Human Geography). Departamentof Geography, SchoolofPhilosophy, Portugueseand Human Science. São Paulo: USP, 2009.

FERNANDES, Bernardo Mançano. Buildinga thinking style regarding agrarian issues: The paradigmatic debateandthe geographical knowledge. PresidentePrudente, São Paulo, 2013.

IBGE. Brazilian Institute of GeographyandStatistics. Census 2010. Available at https://censo2010.ibge.gov.br/. AccessedonMay 5, 2018.

IPECE. Research and Economic Strategy Institute of Ceará. Municipal Basic Profileof São Benedito. 2017. Available at http://www.ipece.ce.gov.br/perfil_basico_municipal/2017/Sao_Benedito.pdf. AccessedonJune 8, 2018.

MARTINS, José de Souza. Expropriationandviolence: the political issuein the countryside. 3rdEdition. São Paulo: Hucitec, 1991.

TERRA, Simone Braga; ZÜGE, Deise Patrícia Portela de Oliveira. Floriculture: the flower productionas a new alternativeofjobandincometo Bagé's (RS) community. Conexão magazine UEPG, v.9, n. 2, Ponta Grossa Jul/Dec, 2013. Availableat www.hist-socialismo.net.

XIMENES, Antônia Vanessa Silva Freire Moraes. The irrigatedperimeterof Araras Norte: socio-territorial implications. Master programessaypresentedatVale do Acaraú StateUniversity - Sobral, 2015. 235 p. 